\title{
Digestibility of Three Feed Ingredients by Catla catla (Hamilton, 1822)
}

\author{
Umalatha H, Gangadhar B*, Hegde G and Sridhar N \\ ICAR-Central Institute of Freshwater Aquaculture, India
}

Submission: June 19, 2017; Published: January 09, 2018

*Corresponding author: Gangadhar B, ICAR-Central Institute of Freshwater Aquaculture, Regional Research Centre, Hesaraghatta Lake P.O., Bangalore- 560 089, India, Email: gbarlaya@yahoo.co.in

\begin{abstract}
Digestibility of dry matter and nutrients by Catla catla was investigated from three feed ingredients-Azolla, soybean and silkworm pupa incorporated at levels ranging from $0-40 \%$ incorporated into a diet consisting equal amounts of rice bran and groundnut oil cake. Total dry matter digestibility (DMD) and protein digestibility of Azolla diets were comparable with the control diet up to 20\% incorporation ( $p>0.05$ ), reducing there after $(\mathrm{p}<0.05)$. On the other hand, fat digestibility increased with the level of Azolla incorporation ( $<<0.05)$. The digestibility of nitrogen-free extract (NFE) was higher $(\mathrm{p}<0.05)$ at 10 and $20 \%$ levels. DMD and protein digestibility of soybean diets were higher $(\mathrm{p}<0.05)$ at $40 \%$ incorporation, and that of fat and NFE were higher $(\mathrm{p}<0.05)$ at both 30 and $40 \%$ levels. Protein digestibility of silkworm pupa diets showed no difference $(p>0.05)$ with that of the control, while fat and NFE digestibility were higher above 20 and 30\% pupa incorporation, respectively. The results of this study would be useful in formulating diets for catla using the ingredients tested.
\end{abstract}

Keywords: Digestibility; Catla catla; Azolla; Soybean; Silkworm pupa

\section{Introduction}

Alternative protein sources and inclusion levels need to be optimized in aqua feeds to make aquaculture production efficient and cost-effective. Best aqua feeds are not defined by nutritional composition, but the degree to which a fish can digest, absorb and assimilate the nutrients. Therefore, digestibility determinations of various feed ingredients are very important to develop cost-effective diet formulations, evaluate ingredient quality, and limit the excretion of nutrients into the environment, which may cause environmental problems [1,2]. Digestibility is the quantification of the digestive processes. It gives a relative measure of the extent to which ingested food and its nutrient components are digested and absorbed by the animal. Apparent digestibility coefficients (ADCs) vary between fish species and feed stuffs. Digestibility of individual ingredients in the compounded diet is considered as one of the important factors affecting the growth of fish [3] and hence, it has been recommended to evaluate the digestibility of each ingredient before its incorporation in the diet.

Azolla pinnata is one of the aquatic plants found in lakes, paddy fields, freshwater ponds, rivers and irrigation channels round the year [4]. It is easy to cultivate and has higher productivity and nutritive value. The use of azolla as a fish feed ingredient is well documented [5-7]. Azolla is rich in protein, total protein ranging from 25 to $30 \%$. Other constituents in Azolla are minerals, chlorophyll, carotinoids, amino acids, and vitamins.

Soybean meal is a prominent ingredient used in prepared diets for fish because of its high protein content and excellent amino acid profile,easy availability, reasonable price and lower fecal nutrient output [8]. Partial substitution of fish meal with soybean meal or its products in feeds at quantities of up to $50-60 \%$ has been in practice for many years $[9,10]$. While aquaculture production continues to expand worldwide to meet the growing demand for fish, the use of soybean products will play an even more important role in providing high-quality protein for various fish species.

Sericulture has become an important cottage industry in countries such as Brazil, China, France, India, Italy, Japan, Korea, and Russia.Spent silkworm pupae,the waste material from silkworm industry, is often discarded in the open environment or used as fertilizer. Due to its high protein content, silkworm pupae meal has been found suitable as a livestock feed, notably for monogastric species and also for ruminants [11]. Studies with Indian major carps and common carp have shown that it 
is more suitable than mustard oil cake and rice bran as a feed ingredient [12]. Studies with common carp [13], catla and rohu [14] and mahseer [15] have shown that it could be included up to $50 \%$ and $30 \%$ levels in carp and mahseer diets respectively.

Catla (Catla catla) is an economically important South Asian freshwater fish. Its higher growth rate and compatibility

\section{Materials and Methods}

Table 1: Ingredient proportion (\%) and proximate composition (\%) of experimental feeds.

\begin{tabular}{|c|c|c|c|c|c|}
\hline Ingredients & Control & $\begin{array}{c}10 \% \text { Azolla/Soya/ } \\
\text { SWP }\end{array}$ & $\begin{array}{c}20 \% \text { Azolla/Soya/ } \\
\text { SWP }\end{array}$ & $\begin{array}{c}30 \% \text { Azolla/Soya/ } \\
\text { SWP }\end{array}$ & $\begin{array}{c}40 \% \text { Azolla/Soya/ } \\
\text { SWP }\end{array}$ \\
\hline Groundnut cake & 45 & 40 & 35 & 30 & 25 \\
\hline Rice bran & 45 & 40 & 35 & 30 & 25 \\
\hline Ragi (Finger Millet) & 9 & 9 & 9 & 9 & 9 \\
\hline Azolla/Soya/SWP & 0 & 10 & 20 & 30 & 40 \\
\hline $\begin{array}{c}\text { Vitamin \& mineral } \\
\text { mix }\end{array}$ & 1 & 1 & 1 & 1 & 1 \\
\hline \multicolumn{6}{|c|}{ Proximate composition } \\
\hline \multicolumn{6}{|c|}{ Azolla feeds } \\
\hline Moisture & $5.79 \pm 0.08$ & $5.60 \pm 0.07$ & $4.87 \pm 0.10$ & $4.53 \pm 0.06$ & $4.60 \pm 0.06$ \\
\hline Crude protein & $26.23 \pm 0.31$ & $25.85 \pm 0.43$ & $25.98 \pm 0.25$ & $24.96 \pm 0.32$ & $24.85 \pm 0.68$ \\
\hline Fat & $7.76 \pm 0.43$ & $7.46 \pm 0.07$ & $7.12 \pm 0.10$ & $6.66 \pm 0.06$ & $6.23 \pm 0.06$ \\
\hline Ash & $6.99 \pm 0.02$ & $8.51 \pm 0.07$ & $10.23 \pm 0.02$ & $12.12 \pm 0.14$ & $13.55 \pm 0.11$ \\
\hline Crude fiber & $7.81 \pm 0.02$ & $7.88 \pm 0.30$ & $6.24 \pm 1.11$ & $6.41 \pm 0.31$ & $6.69 \pm 0.85$ \\
\hline NFE & $45.42 \pm 1.51$ & $44.70 \pm 0.69$ & $45.56 \pm 0.89$ & $45.32 \pm 1.83$ & $44.08 \pm 2.21$ \\
\hline Gross energy (kJ/g) & 17.07 & 16.82 & 16.72 & 16.53 & 16.03 \\
\hline \multicolumn{6}{|c|}{ Soybean feeds } \\
\hline Moisture & $6.64 \pm 0.04$ & $6.09 \pm 0.07$ & $5.15 \pm 0.04$ & $5.99 \pm 0.06$ & $5.08 \pm 0.06$ \\
\hline Crude protein & $27.61 \pm 2.16$ & $29.44 \pm 0.03$ & $30.81 \pm 0.02$ & $31.11 \pm 0.05$ & $33.68 \pm 0.04$ \\
\hline Fat & $6.78 \pm 0.34$ & $6.82 \pm 0.05$ & $5.68 \pm 0.36$ & $4.13 \pm 0.30$ & $4.07 \pm 0.87$ \\
\hline Ash & $6.75 \pm 0.04$ & $7.16 \pm 0.02$ & $7.46 \pm 0.02$ & $7.61 \pm 0.07$ & $7.92 \pm 0.02$ \\
\hline Crude fiber & $7.61 \pm 0.17$ & $7.10 \pm 0.04$ & $6.85 \pm 0.08$ & $5.65 \pm 0.16$ & $5.74 \pm 0.13$ \\
\hline NFE & $44.62 \pm 2.08$ & $43.40 \pm 0.12$ & $44.05 \pm 1.42$ & $45.51 \pm 1.04$ & $43.51 \pm 1.77$ \\
\hline Gross energy (kJ/g) & 16.55 & 16.77 & 16.75 & 16.46 & 16.68 \\
\hline \multicolumn{6}{|c|}{ Silkworm pupa feeds } \\
\hline Moisture & $6.67 \pm 0.02$ & $6.42 \pm 0.02$ & $6.22 \pm 0.01$ & $5.95 \pm 0.01$ & $5.53 \pm 0.02$ \\
\hline Crude protein & $26.74 \pm 0.17$ & $29.27 \pm 0.60$ & $32.97 \pm 0.74$ & $34.91 \pm 0.60$ & $35.65 \pm 1.02$ \\
\hline Fat & $6.92 \pm 0.36$ & $9.02 \pm 0.23$ & $10.28 \pm 0.38$ & $12.47 \pm 0.97$ & $15.45 \pm 1.06$ \\
\hline Ash & $6.65 \pm 0.04$ & $6.20 \pm 0.02$ & $5.81 \pm 0.05$ & $5.52 \pm 0.03$ & $5.38 \pm 0.06$ \\
\hline Crude fiber & $6.83 \pm 0.31$ & $8.66 \pm 1.48$ & $6.29 \pm 0.38$ & $6.35 \pm 0.04$ & $6.61 \pm 0.56$ \\
\hline NFE & $46.18 \pm 0.51$ & $40.42 \pm 1.69$ & $38.43 \pm 0.89$ & $34.81 \pm 0.83$ & $31.38 \pm 2.31$ \\
\hline Gross energy (kJ/g) & 16.68 & 17.08 & 18.06 & 18.73 & 19.46 \\
\hline
\end{tabular}

The basal diet consisted of groundnut cake, rice bran, finger millet (binder) and vitamin- mineral mixture (Table 1). Four experimental diets were formulated with each ingredient, replacing groundnut cake and rice bran of the basal diet at 10 , 20, 30 and $40 \%$ levels. Whole plants of $A$. pinnata were harvested from fish culture ponds, sun dried for 2-3 days, packed in

polythene bags and powdered at requisite quantities before feed preparation. Soybean meal, silkworm pupae, groundnut oil cake, rice bran and finger millet were procured locally. Groundnut oil-cake, soybean meal, silkworm pupae and finger millet were dried and powdered. All the ingredients were sieved through a fine meshed screen $(0.5 \mathrm{~mm})$. The required quantity of the 
ingredients was mixed with hot water to make a dough and then pressed through a hand pelletiser to get uniform sized pellets $(2 \mathrm{~mm})$. The pellets were sun dried and packed in polythene bags till further use.

Digestibility of the test ingredients was estimated in vivo through a short-term trial [16] conducted in 50L indoor plastic tubs at the Regional Research Centre, Bengaluru. Ten fingerlings each of catla (av. wt. $10.11 \pm 1.57 \mathrm{~g}$ ) were maintained in a set of thirty separate aerated aquaria and acclimated to laboratory conditions for a week. Every morning at $10.00 \mathrm{hr}$., each diet was fed to fish in duplicate tanks. The fish were allowed to feed for 6 hours. The pelleted feed was siphoned out at the end of the feeding period. On the following day, fecal matter was collected from each tank by filtering the water with a fine meshed nylon cloth $(15 \mu \mathrm{m})$, dried, pooled and stored for proximate analysis. About $50 \%$ of water from each aquarium was replaced with fresh water every day after fecal matter collection. This feeding and fecal matter collection trial was conducted for a period of 60 days. Proximate composition of pelleted feed and fecal matter was analysed [17]. Energy content of the feed ingredients and diets was calculated using values of $22.6 \mathrm{kJg}^{-1}$ for protein, $38.9 \mathrm{kJg}$ ${ }^{1}$ for lipid and $17.2 \mathrm{kJg}^{-1}$ for carbohydrate as NFE. Dry matter and nutrient digestibility were determined according Maynard \& Loosli [18]. Crude fibre was used as the reference marker $[3,19]$.

Data on digestibility was compared employing one-way analysis of variance. Pair-wise comparison of treatment means was done by Duncan's multiple range test $(p=0.05)$ [20], when a parameter was significant.

\section{Results and Discussion}

The crude protein content of Azolla incorporated diets ranged from 24.85 to $26.23 \%$, while fat and NFE contents varied from 6.23 to $7.76 \%$ and 44.08 to $45.56 \%$ respectively. The values of these nutrients in soybean incorporated feed were in the range of $27.61-33.68 \%, 4.07-6.82 \%$ and $43.40-45.51 \%$ respectively. The crude protein content of silk worm pupae incorporated diets ranged from 26.74 to $35.65 \%$, while fat and NFE contents varied from 6.92 to $15.45 \%$ and 31.38 to $46.18 \%$ respectively. The differences in the major nutrient contents between the diets are attributable to the proximate composition of the ingredients tested.

Table 2: Digestibility (\%, mean \pm SD) of dry matter, protein and fat by Catla catla fed experimental feeds.

\begin{tabular}{|c|c|c|c|c|}
\hline Feeds & Total DMD & Protein Digestibility & Fat Digestibility & NFE Digestibility \\
\hline \multicolumn{5}{|c|}{ Azolla } \\
\hline Control & $60.20 \pm 2.20^{\mathrm{cd}}$ & $68.26 \pm 1.91^{\mathrm{c}}$ & $82.79 \pm 1.47^{\mathrm{a}}$ & $79.31 \pm 1.90^{\mathrm{a}}$ \\
\hline $10 \%$ & $62.48 \pm 0.18^{\mathrm{d}}$ & $75.45 \pm 4.03^{\text {cd }}$ & $87.08 \pm 0.29^{b}$ & $86.66 \pm 0.72^{c}$ \\
\hline $20 \%$ & $55.61 \pm 0.64^{c}$ & $65.44 \pm 0.65^{c}$ & $89.80 \pm 0.08^{c}$ & $83.74 \pm 1.25^{\mathrm{bc}}$ \\
\hline $30 \%$ & $49.34 \pm 2.04^{b}$ & $55.64 \pm 2.58^{b}$ & $95.29 \pm 0.57^{d}$ & $82.14 \pm 0.48^{\mathrm{ab}}$ \\
\hline $40 \%$ & $36.21 \pm 3.33^{\mathrm{a}}$ & $44.91 \pm 1.92^{\mathrm{a}}$ & $96.83 \pm 0.70^{\mathrm{d}}$ & $81.14 \pm 1.16^{\mathrm{ab}}$ \\
\hline \multicolumn{5}{|c|}{ Soy bean } \\
\hline Control & $60.61 \pm 2.29^{a}$ & $69.21 \pm 2.65^{\mathrm{a}}$ & $80.93 \pm 0.52^{\mathrm{a}}$ & $76.36 \pm 1.88^{\mathrm{a}}$ \\
\hline $10 \%$ & $60.25 \pm 1.76^{\mathrm{a}}$ & $68.76 \pm 1.74^{a}$ & $81.16 \pm 0.17^{a}$ & $76.68 \pm 1.15^{\mathrm{a}}$ \\
\hline $20 \%$ & $60.08 \pm 1.10^{\mathrm{a}}$ & $71.37 \pm 2.59^{a}$ & $82.70 \pm 1.84^{a}$ & $77.10 \pm 0.87^{\mathrm{a}}$ \\
\hline $30 \%$ & $63.25 \pm 0.98^{\mathrm{a}}$ & $72.25 \pm 0.64^{\mathrm{a}}$ & $86.43 \pm 0.80^{\mathrm{b}}$ & $80.68 \pm 0.81^{b}$ \\
\hline $40 \%$ & $68.71 \pm 0.14^{b}$ & $84.96 \pm 0.15^{b}$ & $88.32 \pm 0.08^{b}$ & $84.83 \pm 0.19^{c}$ \\
\hline \multicolumn{5}{|c|}{ Silkworm pupa } \\
\hline Control & $61.28 \pm 3.26^{b}$ & $68.57 \pm 3.41^{\mathrm{a}}$ & $85.20 \pm 1.35^{\mathrm{a}}$ & $78.61 \pm 0.19^{a}$ \\
\hline $10 \%$ & $58.61 \pm 0.40^{\mathrm{ab}}$ & $69.04 \pm 0.33^{a}$ & $84.18 \pm 0.22^{\mathrm{a}}$ & $77.37 \pm 0.06^{\mathrm{a}}$ \\
\hline $20 \%$ & $58.43 \pm 0.52^{\mathrm{ab}}$ & $70.87 \pm 0.45^{a}$ & $88.00 \pm 0.39^{b}$ & $79.56 \pm 0.47^{a}$ \\
\hline $30 \%$ & $59.00 \pm 1.77^{\mathrm{ab}}$ & $69.64 \pm 1.29^{a}$ & $94.66 \pm 0.87^{c}$ & $85.73 \pm 0.54^{b}$ \\
\hline $40 \%$ & $55.31 \pm 2.63^{\mathrm{a}}$ & $67.17 \pm 1.41^{\mathrm{a}}$ & $93.72 \pm 0.30^{c}$ & $85.40 \pm 0.63^{b}$ \\
\hline
\end{tabular}

DMD and the major nutrient digestibility values recorded are given in Table 2. DMD and protein digestibility (PD) of Azolla diets were comparable with the control diet up to $20 \%$ incorporation $(\mathrm{p}>0.05)$, which showed a reduction thereafter $(p<0.05)$. On the other hand, fat digestibility increased with the level of Azolla incorporation $(\mathrm{p}<0.05)$. The digestibility of NFE was higher $(\mathrm{p}<0.05)$ at 10 and $20 \%$ levels. DMD and PD of soybean diets were higher $(\mathrm{p}<0.05)$ at $40 \%$ incorporation, and that of fat and NFE were higher $(\mathrm{p}<0.05)$ at both 30 and $40 \%$ levels. Protein digestibility of silkworm pupa diets showed no difference $(p>0.05)$ with that of the control, while fat and NFE digestibility were higher above 20 and $30 \%$ pupa incorporation, respectively.

Azolla pinnata, has been considered a potential source of nutrients which is directly used as a food component by a number of herbivorous fish [21,22]. In the present study, 
incorporation of azolla up to $20 \%$ did not have any adverse effect on DMD and protein digestibility, both decreasing $(\mathrm{p}<0.05)$ at higher inclusion levels. Asadujjaman \& Hosain [23] reported poor growth of catla fed fresh Azolla as compared to those fed control diet consisting of rice bran, wheat bran and mustard cake (30:30:40). According to Datta [5], Azolla can be incorporated up to $25 \%$ in the diet of another Indian major carp L. rohita. Inclusion of $A$. pinnata at $10-25 \%$ replacing fish meal in the diet of rohu has yielded positive growth due to the presence of $\omega-6$ fatty acids [24]. Azolla inclusion at $40 \%$ enhanced growth in $L$. rohita fingerlings [25]. The differences in the utilization of Azolla by the two major carps can be attributed to their feeding habits. Catla is omnivorous, mainly subsisting on vegetable matter, algae and microcrustaceans [25-27]; on the other hand, rohu is herbivorous, mainly consuming phytoplankton and submerged vegetation [28-30]. Addition of more than 25\% Azollain fish diet has led to reduced food utilisation, poor growth performance and altered muscle composition [31]. A. pinnata protein is reported to be limiting in tryptophan and slightly deficient in threonine [32], increasing the demand for the deficient amino acids with increased concentration of Azolla in the diet. Catla requires $4.5 \%$ and $1.03 \%$ of dietary protein as threonine and tryptophan, respectively [33].

The DMD and protein digestibility of soybean diets were higher $(\mathrm{P}<0.05)$ at $40 \%$ incorporation and that of fat and NFE were higher $(\mathrm{p}<0.05)$ at both 30 and $40 \%$ levels. Negative effects on PD in soybean feeding, attributable to trypsin inhibitors and phytic acid, have been reported by Francis et al. [34]. However, Venou et al. [35] observed that soy inclusion did not have any effect on nutrient digestibility. Heat treatment destroys a large number of anti-nutritional factors contained in plant derived ingredients and improves their utilization by fish [34]. Since hot water was used during the preparation of feeds in the present study, similar deactivation of anti-nutrients is expected, mitigating their adverse effects on digestibility.

The digestibility of the protein fraction of soybean products has been reported to be more than $90 \%$ for species such as common carp [36], channel catfish [37], tilapia [38] and silver perch [39]. However, Hossain et al. [40] reported apparent PD value of $84.06 \%$ with rohu. The highest PD recorded in the present study was $84.96 \%$. This value is comparable to the value of $85 \%$ reported for channel catfish [41], $84.67 \%$ for tilapia [42], 86.8\% for carp [43], but higher than the values of $69.5 \%$ in jalawat [44], 76.08\% in Anabas testudineus [45] and $80 \%$ in rainbow trout [46]. Eid \& Matty [47] and Atack et al. [48] reported PD values of $83.2 \%$. and $83.7 \%$ respectively for soybean meal in common carp. Highest lipid digestibility value observed in catla was $88.32 \%$. Lipid digestibility values of 81 and $90 \%$ were reported earlier for channel catfish [49] and hybrid tilapia [38]. The present results suggest that soybean meal at the tested levels of incorporation does not affect lipid digestibility.

Protein digestibility of silkworm pupa diets showed no difference $(\mathrm{P}>0.05)$ with that of the control, while fat and NFE digestibility were higher above 20 and $30 \%$ pupa incorporation, respectively. Complete replacement of dietary protein (30\%) by silkworm pupa resulted in significantly better growth performance of catla fingerlings than the control diet [50]. Studies with catla and rohu [14] have shown the best growth at $30 \%$ pupa inclusion, it being the highest level tried. Silkworm pupa meal could be used up to $50 \%$ in the diet of common carp without adversely affecting growth and flesh quality [13]. The highest protein digestibility value recorded for pupa diets with catla was $70.87 \%$. For rohu, Hossain et al. [40] and Jayaram \& Shetty [14] reported fairly high APD values of $85.21 \%$ and 91.89\% with silkworm pupae. Higher APD values were also recorded in rainbow trout (85\%, Hastings, 1969) and tilapia (85.74\%,) [42]. In contrast, Kim [43] observed low APD (63.9\%) in common carp. Fat digestibility in common carp increased with increasing level of pupa meal [51]. In the present study also, higher fat digestibility was observed with pupa incorporated diets. Incorporation of pupa reduced dietary starch levels due to which an increase in NFE digestibility was recorded in catla, as observed in other species [52].

The digestibility of fat by fish is known to be quite variable and depends on a number of factors, including the source [53]. In the present study, higher fat digestibility was observed with the test diets, indicating that the crude fat from all the ingredients was well digested by catla. This is particularly evident in the case of Azolla and soybean, where, in spite of a reduction in dietary fat content with their incorporation, there was an improvement in fat digestibility. Dietary fat at higher levels (>10.28\%) had a negative effect on PDingilthead bream [52]. In contrast, in catla, silkworm pupa diets having fat above $10 \%$ recorded higher $(\mathrm{p}<0.05)$ fat digestibility. Lipid supplementation studies have shown levels of 5-12\% to be optimal for carp diets [54-56]. Formulated diets having 9.99, 13.26 and $16.91 \%$ fat with 3,6 and $9 \%$ pupa oil supplementation, respectively, had higher fat digestibility in common carp compared to control diet having $7.35 \%$ fat [57].

Carbohydrate digestibility in fish depends on the type, inclusion level and the processing treatments applied to it as reported for carp [58], yellow tail, Seriola quinqueradiata [59], rainbow trout, Salmo gairdneri [60] and cod, Gadus morhua [61]. The digestibility of NFE in the present study ranged between 77.37 and $86.66 \%$. Herbivores and omnivores fish are known to utilize carbohydrate better [42]. Catla, being an omnivore, is expected to better utilize carbohydrate from feed ingredients. Dietary fat level is reported to have a negative effect on starch digestibility in sea bream [52]. In the present study, the increase in dietary fat levels due to pupa incorporation, however, did not have a negative effect on NFE digestibility in catla $[62,63]$.

\section{Conclusion}

The study reveals the usefulness of the tested ingredients for inclusion in catla diets. Azolla can be profitably used up to $20 \%$, while due to the higher protein and fat digestibility, soybean 
and silkworm pupae can be used at $40 \%$ and $30 \%$, respectively. Further, there is scope for trying still higher levels of soybean in the diet of catla since the highest level tried has shown the best results.

\section{Acknowledgement}

The authors are grateful to the Director, CIFA, Bhubaneswar for the infrastructure facility provided.

\section{References}

1. Gatlin DM, Hardy RW (2002) Manipulations of diets and feeding to reduce losses of nutrients in intensive aquaculture. In: Tomasso JR (Ed.), Aquaculture and the Environment in the United States. World Aquaculture Society, Baton Rouge, Louisiana, USA, pp. 155-165.

2. Montaño-V, Shimada J, Vásquez AC, Viana MT (2002) Methods of measuring feed digestibility in the green abalone (Haliotis fulgens). Aquaculture 213: 339-346.

3. De Silva SS, Shim KF, Khim OA (1990) An evaluation of the method used in digestibility estimations of a dietary ingredient and comparisons of external and internal markers and time of faces collection in digestibility studies in the fish Oreochromis aureus (Steindachner). Reproduct Nut Dev 30(2): 215-226.

4. Lumpkin TA, Plucknett DL (1982) Azolla as a Green Manure: Use and Management in Crop Production. Westview Press, Boulder, Colorado, USA, pp. 230.

5. Dutta SN (2011) Culture of azolla and its efficacy in diet of Labeo rohita. Aquaculture 310: 376-379.

6. Gangadhar B, Sridhar N, Saurabh S, Raghavendra CH, Hemaprasanth KP, et al. (2014) Growth response of Cirrhinus mrigala to azolla (Azolla pinnata) incorporated diets during fry to fingerling rearing. Fish Technol 51(3): 156-161.

7. Gangadhar B, Sridhar N, Saurabh S, Raghavendra CH, Hemaprasanth KP, et al. (2015) Effect of azolla-incorporated diets on the growth and survival of Labeo fimbriatus during fry-to fingerling rearing. Cogent Food and Agric 1: 1055539.

8. Castro CAC, Hernández LHH, Araiza MAF, Pérez TR, López OA (2011) Effects of diets with soybean meal on the growth, digestibility, phosphorus and nitrogen excretion of juvenile rainbow trout Oncorhynchus mykiss. Hidrobiológica 21(2): 118-125.

9. Dawood MAO, Koshio S, Ishikawa M, Yokoyama S (2015) Effects of partial substitution of fish meal by soybean meal with or without heat-killed Lactobacillus plantarum (LP20) on growth performance, digestibility, and immune response of Amberjack, Seriola dumerili juveniles. Biomedical Res Int 514196: 11.

10. Priyadarshini M, Manissery JK, Gangadhara B, Rao LM, Keshavanath $P$ (2015) Growth performance, body composition and digestive enzyme activity of common carp (Cyprinus carpio) fry fed on soybean and horse gram supplemented diets. Int J Aquacult 5(17): 1-7.

11. Trivedy K, Kumar SN, Mondal M, Kumar Bhat CA (2008) Protein banding pattern and major amino acid component in de-oiled pupal powder of silkworm, Bombyxmori Linn. J Entomology 5(1): 10-16.

12. Chakraborty RD, Sen PR, Chatterjee DK, Kowtal GV (1973) Observations on the relative usefulness of different feed for carp spawn and fry. Inland Fisheries Soc India 5: 182-188.

13. Nandeesha MC, Gangadhara B, Varghese TJ, Keshavanath P (2000) Growth response and flesh quality of common carp, Cyprinus carpio fed with high levels of non-defatted silkworm pupae. Asian Fish Sci 13(2000): 235-242.
14. Jayaram MG, Shetty HPC (1980) Influence of different diets on the proximate body composition of Catla catla, Labeo rohita and Cyprinus carpio. Mysore J Agril Sci 14: 381-384.

15. Shyama S, Keshavanath P (1993) Growth response of Tor khudree to silkworm pupa incorporated diets. In: Kaushik SJ, Luquet P (Eds.), Fish Nutrition in Practice, INRA, Paris, France, pp. 779-783.

16. Nadeesha MC, Gangadhara B, Varghese TJ, Keshavanath P (1998) Effect of feeding Spirulina platensis on the growth, proximate composition and organoleptic quality of common carp, Cyprinus carpio L. Aquacult Res 29(5): 305-312.

17. AOAC (1995) Official Methods of Analysis. (16 $6^{\text {th }}$ edn), Association of Official Analytical Chemists, Washington DC, USA.

18. Maynard LA, Loosli JK (1972) Animal Nutrition. (6 $6^{\text {th }}$ edn), McGraw-Hill, New York, USA.

19. Krontveit RI, Bendiksen EA, Aunsmo A (2014) Field monitoring of feed digestibility in Atlantic salmon farming using crude fiber as an inert marker. Aquaculture 426-427.

20. Duncan DB (1955) Multiple range and multiple F-tests. Biometrics 11(1): 1-42.

21. Cassani JR (1981) Feeding behavior of under yearling hybrids of grass carp Ctenopharyngadon idella female and the bighead Hypophthalmichtys nobilis male on selected species of aquatic plants. J Fish Biol 18(2): 127-138.

22. Okeyo DO (1989) Herbivory in Freshwater Fishes: A Review. Bamidgeh 41(3): 79-97.

23. Asadujjaman M, Hossain MA (2016) Fish growth, yield and economics of conventional feed and weed based polyculture in ponds. J Fish 4(1): 353-360.

24. Mohanty SN, Dashm SP (1995) Evaluation of Azolla caroliniana for inclusion in carp diet. J Aqua Trop 10(4): 343-353.

25. Panigrahi S, Choudhary D, Sahoo JK, Das SS, Rath RK (2014) Effect of dietary supplementation of Azolla on growth and survibility of Labeo rohita fingerlings. Asian J Animal Sci 9(1): 33-37.

26. Natarajan AV, Jhingran AG (1961) Index of Preponderance - a method of grading the food elements in the stomach analysis of fishes. Indian J Fish 8(1): 54-59.

27. Jhingran VG (1991) Fish and Fisheries of India. Hindustan Publishing Corporation, Delhi, India, pp. 954.

28. Dasgupta M (1996) Alimentary canal of Catla catla (Hamilton) in relation to its food and feeding habits. Ind J Fisheries 43(4): 385-387.

29. Jhingran VG, Pullin RSV (1985) A Hatchery Manual for the Common, Chinese and Indian Major Carps. Asian Development BankInternational Center for Living Aquatic Resources Management. Manila, Philippines, p. 191.

30. Wahab MA, Ahmed ZF, Haq MS, Begum M (1994) Compatibility of silver carp in the polyculture of cyprinid fishes. Prog. Agric 5(2): 221-227.

31. Joseph A, Sherief PM, James T (1994) Effect of different dietary inclusion levels of Azolla pinnata on the growth, food conversion and muscle composition of Etroplus suratensis (Bloch). J Aqua Trop 9(1): 87-94.

32. Almazan GJ, Pullin RSV, Angels AF, Manolo TA, Agbayani RA et al. (1986) Azolla pinnata as dietary component for Nile tilapia, Oreochromis niloticus. In: Maclean JL, Dizonand LB, Hosillos LV (Eds.) The First Asian Fisheries Forum Proceedings. Asian Fisheries Society, Manila, Philippines, pp. 523-528.

33. Murthy HS (2003) Nutrient requirements of Indian major carps. Global Aquaculture Advocate pp. 58-59. 
34. Francis G, Makkar HPS, Becker K (2000) Antinutritional factors present in plant-derived alternate fish feed ingredients and their effects in fish. Aquaculture 199(2001): 197-227.

35. Venou B, Alexis MN, Fountoulaki E, Haralabous J (2006) Effects of extrusion and inclusion level of soybean meal on diet digestibility, performance and nutrient utilization of gilthead sea bream (Sparus aurata). Aquaculture 261: 343-356.

36. Takeuchi O, Sato S, Horiuchi T, Hoshino K, Takeda K, et al. (2002) Cutting edge: role of Toll-like receptor 1 in mediating immune response to microbial lipoproteins. J Immunol 169(1): 10-14.

37. Wilson RP, Poe WE (1985) Apparent digestible protein and energy coefficients of common feed ingredients for channel catfish. Prog Fish Cult 47(3): 154-158.

38. Hanley F (1987) The digestibility of foodstuffs and the effects of feeding selectivity on digestibility determinations in tilapia, Oreochromis niloticus (L). Aquaculture 66: 163-179.

39. Allan GL, Parkinson S, Booth MA, Stone DAJ, Rowland SJ, et al. (2000) Replacement of fish meal in diets for Australian silver perch, Bidyanus bidyanus: I. Digestibility of alternative ingredients. Aquaculture 186: 293-310.

40. Hossain MA, Nahar N, Kamal M (1997) Nutrient digestibility coefficients of some plant and animal proteins for rohu (Labeo rohita). Aquaculture 151: 37-45.

41. Brown PB, Strange RJ, Robbins KR (1985) Protein digestibility coefficients for yearling channel catfish fed high protein feedstuffs. Prog Fish-Cult 47: 94-97.

42. Hossain MA, Nahar N, Kamal M, Islam MN (1992) Nutrient digestibility coefficients of some plant and animal proteins for tilapia (Oreochromis mossambicus). J Aqua Trop 7(2): 257-265.

43. Kim YK (1974) Determination of true digestibility of dietary protein with $\mathrm{Cr}_{2} \mathrm{O}_{3}$ containing diet. Nippon Suisan Gakkaishi 40: 651-654.

44. Law AT (1984) Nutritional study of Jelawat, Leptobarbus hoevenii (Bleeker), fed on pelleted feed. Aquaculture 413: 227-233.

45. Ali H, Haque MM, Chowdhury MMR, Shariful MI (2009) In vitro protein digestibility of different feed ingredients in Thai koi (Anabas testudineus). J Bangladesh Agril Univ 7(1).

46. Smith RR, Peterson MC, Allerd AC (1980) Effects of leaching on apparent digestion coefficients of feedstuffs for salmonids. Prog Fish Cult 42(4): 195-199.

47. Eid AE, Matty AJ (1989) A simple In vitro method for measuring protein digestibility. Aquaculture 79: 111-119.

48. Atack TH, Jauncey K, Matty AJ (1979) The utilization of some singlecelled protein by fingerling mirror carp (Cyprinus carpio). Aquaculture 18: $337-348$.

This work is licensed under Creative

Commons Attribution 4.0 Licens

DOI: 10.19080/OFOAJ.2018.05.555672
49. Cruz ME (1975) Determination of Nutrient Digestibility in Various Feedstuffs for Channel Catfish. Ph.D. Dissertation. Auburn University, USA.

50. Hasan MR (1991) Studies on the use of poultry offal and silk worm pupae as dietary protein sources for Indian major carp, Catla (Hamilton). Proc. Workshop Bangladesh Agric. Univ. Res. Progress held at Bangladesh Agricultural University, Mymensingh, Bangladesh, pp. 415-428.

51. Nandeesha MC, Srikanth GK, Keshavanath P,Varghese T, Basavaraja J, et al. (1990) Effect of non-defatted silkworm pupae in diets on the growth of common carp, Cyprinus carpio. Biological Wastes 33: 17-23.

52. Fountoulaki E, Alexis MN, Nengas I, Venou B (2005) Effect of diet composition on nutrient digestibility and digestive enzyme levels of gilthead sea bream (Sparusaurata L.). Aquacult Res 36(13): 12431251.

53. Appleford P, Anderson TA (1997) Apparent digestibility of tuna oil for common carp Cyprinus Carpio- effect of inclusion level adaptation time. Revista Brasileira De Zootecnia-Brazilian J Ani Sci 148: 143-151.

54. Bazaz MM, Keshavanath P (1993) Effect of feeding different levels of sardine oil on growth muscle composition and digestive enzyme activities of mahaseer Tor khudree. Aquaculture 115: 111-119.

55. Hassan M, Blanc PJ, Granger LM, Pareilleux A, Goma G (1996) Influence of nitrogen and iron limitations on lipid production by Cryptococcus curvatus grown in batch and fed-batch culture. Process Biochem 31(4): 335-361.

56. Gangadhara B, Nandeesha MC, Varghese TJ, Keshavanath P (1997) Effect of varying protein and lipid levels on the growth of rohu, Labeo rohita. Asian Fish Sci 10: 139-147.

57. Nandeesha MC, Gangadhara B, Manissery JK (1999) Silkworm pupa oil and sardine oil as additional energy sources in the diet of common carp, Cyprinus carpio. Asian Fish Sci 12(3): 207-215.

58. Chiou JY, Ogino C (1975) Digestibility of starch in carp. Bull Japanese Soc Scientific Fisheries 41(4): 465-466.

59. Shimeno S, Hosokawa H, Takeda M (1978) In the Diet of Carnivorous Fish. FAO/EIFAC/78/Symp. E/5, p. 1-32.

60. Ufodike EBC, Matty AJ (1984) Nutrient digestibility and growth responses of rainbow trout (Salmo gairdneri) fed different levels of cassava and rice. Hydrobiologia 119(2): 83-88.

61. Hemre GI, Lie A, Lied E, Lambertsen G (1989) Starch as an energy source in feed for cod (Gadus morhua): Digestibility and retention. Aquaculture 80: 261-270.

62. Hastings WH (1969) Nutritional score. In: Neuhans OW, Halver JE (Eds.) Fish in Research. Academic press, New York, USA, pp. 263-292.

63. Wahab MA, Kibria MG (1994) Katha and kua fisheries - unusual fishing methods in Bangladesh. Aquacult News 18: 24.

Your next submission with Juniper Publishers
will reach you the below assets
- Quality Editorial service
- Swift Peer Review
- Reprints availability
- E-prints Service
- Manuscript Podcast for convenient understanding
- Global attainment for your research
- Manuscript accessibility in different formats
( Pdf, E-pub, Full Text, Audio)
- Unceasing customer service
Track the below URL for one-step submission
https://juniperpublishers.com/online-submission.php

